\title{
Amplification of Nitric Oxide Synthase Expression by Nitric Oxide in Interleukin 1 $\beta$-stimulated Rat Mesangial Cells
}

\author{
Heiko Mühl and Josef Pfeilschifter \\ Department of Pharmacology, Biozentrum, University of Basel, CH-4056 Basel, Switzerland
}

\begin{abstract}
Nitric oxide (NO) plays an important role in immunological reactions as a host defense mechanism against tumor cells and invasive microorganisms, but it may also damage healthy tissue. The excessive formation of NO in IL-1ßstimulated renal mesangial cells not only alters glomerular filtration, but it may also cause tissue injury and thus contribute to the pathogenesis of certain forms of glomerulonephritis. We report here that, although NO alone has no evident effect on NO synthase expression, it potently augments IL-1 $\beta$-stimulated NO synthase expression in mesangial cells. NO donors such as sodium nitroprusside and $S$ nitroso- $N$-acetyl-D,L-penicillamine markedly increase IL$1 \beta$-induced NO synthase mRNA and protein levels as well as enzyme activity. Nuclear run-on experiments suggest that NO acts to increase $I L-1 \beta$-induced NO synthase gene expression at the transcriptional level. Furthermore, inhibition of NO synthesis by different pharmacological approaches reduces IL-1 $\beta$-induced NO synthase expression, thus suggesting that NO functions in a positive feedback loop that speeds up and strengthens its own biosynthesis. We suggest that this potent amplification mechanism forms the basis for the excessive formation of $\mathrm{NO}$ in acute and chronic inflammatory diseases. (J. Clin. Invest. 1995. 95:1941-1946.) Key words: nitric oxide • nitric oxide synthase $\bullet$ interleukin $1 \cdot$ mesangial cells $\bullet$ nitric oxide donors
\end{abstract}

\section{Introduction}

Nitric oxide (NO), ${ }^{1}$ a free radical gas produced by many cell types, mediates blood vessel relaxation, functions as a neurotransmitter in the central and peripheral nervous system, medi-

Address correspondence to J. Pfeilschifter, Department of Pharmacology, Biozentrum, University of Basel, Klingelbergstrasse 70, $\mathrm{CH}-4056$ Basel, Switzerland. Phone: 61-267-2223; FAX: 61-267-2208.

Received for publication 1 August 1994 and in revised form 28 November 1994.

1. Abbreviations used in this paper: DAHP, 2,4-diamino-6-hydroxypyrimidine; L-NMMA, $N^{\mathrm{G}}$-monomethyl-L-arginine; NO, nitric oxide; NOS, NO synthase; SNAP, $S$-nitroso- $N$-acetyl-D,L-penicillamine; SNP, sodium nitroprusside.

J. Clin. Invest.

(C) The American Society for Clinical Investigation, Inc.

0021-9738/95/04/1941/06 \$2.00

Volume 95, April 1995, 1941-1946 ates macrophage cytotoxicity during host defense, and leads to tissue injury in some inflammatory and autoimmune diseases (1-5). Increasing evidence indicates that NO orchestrates acute and chronic inflammatory processes and contributes to the pathomechanisms of septic shock (6); contributes to the destruction of pancreatic islet cells during the development of insulin-dependent type 1 diabetes (4); and adjuvant arthritis (7), progression of renal failure $(8,9)$, and neural destruction in vascular stroke and other neurodegenerative diseases (10). The careful control of this extremely reactive molecule is essential for the prevention of deleterious inflammatory reactions. Whereas the activity of the constitutive brain and endothelial cell NO synthases (NOS) are mainly regulated posttranslationally by cytoplasmic $\mathrm{Ca}^{2+}$ levels or phosphorylation by a variety of protein kinases, the inducible NO synthase is regulated primarily at a transcriptional level. Once induced, the latter enzyme synthesizes NO for long periods of hours and days (1, $3,5)$.

We have used renal mesangial cells, a specialized type of vascular smooth muscle cell that takes part in the regulation of the glomerular filtration rate (11). These cells respond to endothelial-derived NO with increased levels of intracellular cGMP $(12,13)$ and express a macrophage type of NO synthase when exposed to inflammatory cytokines $(14-16)$. In the present report we have addressed possible self-regulatory mechanisms modulating the expression of NO synthase in mesangial cells.

\section{Methods}

Materials. Recombinant human IL-1 $\beta$ was generously supplied by Dr. Klaus Vosbeck (Ciba-Geigy Ltd., Basel, Switzerland); sodium nitroprusside (SNP) and 2,4-diamino-6-hydroxypyrimidine were from Sigma Chemical Co. (Buchs, Switzerland); $N^{\mathrm{G}}$-monomethyl-L-arginine and $S$ nitroso- $N$-acetyl-D,L-penicillamine (SNAP) were from Alexis Corporation (Läufelfingen, Switzerland); sepiapterin was purchased from Dr. B. Schirks Laboratories (Jona, Switzerland); the cDNA clone pMacNOS, coding for the inducible macrophage NO synthase, was kindly provided by Dr. J. Cunningham (Brigham and Women's Hospital, Harvard Medical School, Boston, MA); the cDNA clone pEX6, coding for human $\beta$-actin, was a gift from Dr. U. Aebi (Maurice E. Müller Institute Biozentrum, University of Basel, Basel, Switzerland); nylon membranes were purchased from DuPont de Nemours International (GeneScreen; Regensdorf, Switzerland); [ $\left.{ }^{32} \mathrm{P}\right] \mathrm{dATP}$ (specific activity $3,000 \mathrm{Ci} /$ mmol) was from Amersham (Dübendorf, Switzerland); cell culture media and nutrients were from Gibco BRL (Basel, Switzerland), and all other chemicals were either from Merck (Darmstadt, Germany) or Fluka Chemie AG (Buchs, Switzerland).

Cell culture. Rat glomerular mesangial cells were cultured and cloned as described previously (17). The cells were grown in RPMI 1640 supplemented with $10 \%$ ( vol/vol) fetal calf serum, penicillin ( 100 
$\mathrm{U} / \mathrm{ml})$, streptomycin $(100 \mu \mathrm{g} / \mathrm{ml})$, and bovine insulin at $0.66 \mathrm{U} / \mathrm{ml}$ (Sigma Chemical Co.). For the experiments, passages 9-16 were used.

Nitrite analysis. Nitrite production by rat glomerular mesangial cells was measured as a readout for NO synthase activity as described previously (18). Confluent mesangial cells in 24-well plates were washed twice with PBS and incubated in DME without phenol red and supplemented with $0.1 \mathrm{mg} / \mathrm{ml}$ of fatty acid-free BSA with or without agents for the indicated time periods. Thereafter, the medium was withdrawn and nitrite was measured by mixing $200 \mu \mathrm{l}$ of the supernatant with 50 $\mu \mathrm{l}$ of Griess reagent. The absorbance at $550 \mathrm{~nm}$ was measured and the nitrite concentration was determined using a calibration curve with sodium nitrite standards.

Citrulline assay. Mesangial cells were lysed by sonification and the homogenate was centrifuged for $1 \mathrm{~h}$ at $4^{\circ} \mathrm{C}$ at $100,000 \mathrm{~g}$. Protein content of the cytosol was determined and assayed for NOS activity. The conversion of L-arginine to L-citrulline was assayed as reported previously (18). Cytosolic samples $(50 \mu \mathrm{l})$ were incubated for $30 \mathrm{~min}$ at $38^{\circ} \mathrm{C}$ with $\mathrm{L}-\left[{ }^{14} \mathrm{C}\right]$ arginine $(5 \mu \mathrm{M} ; 5 \mathrm{nCi})$, dithiothreitol $(1 \mathrm{mM})$, NADPH $(1.0 \mathrm{mM})$, flavin adenine dinucleotide $(1.0 \mu \mathrm{M})$, and $(6 R)-5,6,7,8$ tetrahydro-L-biopterin dihydrochloride $(0.1 \mathrm{mM})$ in a final vol of 150 $\mu \mathrm{l}$. Some experiments were done in the absence of the cofactors and in the presence of $N^{\mathrm{G}}$-monomethyl-L-arginine (L-NMMA, $5 \mathrm{mM}$ ). The reaction was stopped by heating to $90^{\circ} \mathrm{C}$ for $2 \mathrm{~min}$. After addition of sodium citrate ( $20 \mathrm{mM}, \mathrm{pH} 2.2$; total vol $230 \mu \mathrm{l}$ ) and centrifugation, 2 $\mathrm{ml}$ of a buffer containing EDTA $(2 \mathrm{mM})$, sodium acetate $(20 \mathrm{mM}, \mathrm{pH}$ $5.5)$, and L-citrulline $(0.1 \mathrm{mM})$ was added. The mixture was loaded onto a strongly acidic cation exchange column (AG $50 \mathrm{~W}-\mathrm{X} 8, \mathrm{Na}^{+}$form; Bio-Rad Laboratories, Glattbrugg, Switzerland). The flowthrough and the eluate $(2 \mathrm{ml}$ of water $)$ were collected and radioactivity was quantified in a $\beta$-counter.

Northern blot analysis. Total cellular RNA was extracted from mesangial cell pellets using the guanidinium thiocyanate/cesium chloride method (19). Samples of $25 \mu \mathrm{g}$ RNA were separated on $0.8 \%$ agarose gels containing $0.66 \mathrm{M}$ formaldehyde before transfer to GeneScreen membranes (New England Nuclear, Boston, MA). After baking at $80^{\circ} \mathrm{C}$ for $2 \mathrm{~h}$ and prehybridization for $4 \mathrm{~h}$, the filters were hybridized for 16$18 \mathrm{~h}$ to a ${ }^{32} \mathrm{P}$-labeled SmaI cDNA insert from pMac-NOS (20). To correct for variations in RNA amount, the NOS probe was stripped with boiling $0.1 \times \mathrm{SSC}$ buffer ( $3 \mathrm{M} \mathrm{NaCl}, 0.3 \mathrm{M}$ sodium citrate), $1 \%$ (wt/ vol) SDS, and the blots were rehybridized to the ${ }^{32} \mathrm{P}$-labeled BamHI/ SalI cDNA insert from clone pEX 6 , coding for $\beta$-actin. DNA probes $\left(\sim 2 \times 10^{6} \mathrm{cpm} / \mathrm{ml}\right)$ were radioactively labeled with a- $\left[{ }^{32} \mathrm{P}\right] \mathrm{dATP}$ by random priming (Boehringer Mannheim, Mannheim, Germany). Hybridization reactions were performed in $50 \%$ ( $\mathrm{vol} / \mathrm{vol}$ ) formamide, $5 \times$ SSC, $10 \times$ Denhardt's solution, $0.5 \%$ (wt/vol) SDS, and $250 \mu \mathrm{g} / \mathrm{ml}$ salmon sperm DNA. Filters were washed three times in $2 \times$ SSC, $0.1 \%$ SDS at room temperature for $30 \mathrm{~min}$, and then in $2 \times$ SSC, $2 \%$ SDS at $65^{\circ} \mathrm{C}$ for $30 \mathrm{~min}$. Filters were exposed for 6-48 h to X-Omat XAR film (Eastman Kodak Co., Rochester, NY) using intensifying screens.

Nuclear run-on transcription. Preparation of nuclei was done as described (21). For the run-on transcription assay, the nuclei suspension was mixed with $0.2 \mathrm{ml}$ of $2 \times$ reaction buffer ( $100 \mathrm{mM}$ Hepes, $\mathrm{pH} 8.0 /$ $10 \mathrm{mM} \mathrm{MgCl} 2 / 300 \mathrm{mM} \mathrm{KCl} / 200 \mathrm{U}$ of RNasin [Boehringer Mannheim] per $\mathrm{ml} / 1 \mathrm{mM}$ each ATP, GTP, and CTP/150 $\mu \mathrm{Ci}$ of $\left[{ }^{32} \mathrm{P}\right]$ UTP $[3,000$ $\mathrm{Ci} / \mathrm{mmol}]$ ) and incubated for $30 \mathrm{~min}$ at $30^{\circ} \mathrm{C}$. Transcription was stopped by adding $20 \mu \mathrm{g}$ of DNase I, followed by $80 \mu \mathrm{g}$ of proteinase $\mathrm{K}$. The ${ }^{32} \mathrm{P}$-labeled RNA was purified by extraction with phenol/chloroform and two sequential precipitations with ammonium acetate. Equal amounts of labeled RNA $\left(8 \times 10^{7} \mathrm{dpm} / \mathrm{ml}\right)$ were hybridized in $50 \%$ formamide/ $5 \times \mathrm{SSC} / 5 \times$ Denhardt's solution $/ 1 \% \mathrm{SDS}(1 \times \mathrm{SSC}=150 \mathrm{mM} \mathrm{NaCl} /$ $15 \mathrm{mM}$ sodium citrate, $\mathrm{pH} 7.0$ ) at $42^{\circ} \mathrm{C}$ for $72 \mathrm{~h}$. Filters contained 10 $\mu \mathrm{g}$ each of linearized plasmids immobilized on GeneScreen membranes after blotting in $12 \times$ sodium chloride sodium phosphate EDTA buffer with a dot-blot apparatus. After hybridization, filters were rinsed for 30 $\min$ in $2 \times \mathrm{SSC}$ at $60^{\circ} \mathrm{C}$, for $5 \mathrm{~min}$ in $2 \times \mathrm{SSC}$ containing $10 \mu \mathrm{g}$ of RNAse A per ml at $37^{\circ} \mathrm{C}$, and finally for $1 \mathrm{~h}$ in $2 \times \mathrm{SSC}$ at $37^{\circ} \mathrm{C}$. Filters were air-dried and evaluated by PhosphorImaging (Molecular Dynamics, Inc., Sunnyvale, CA).
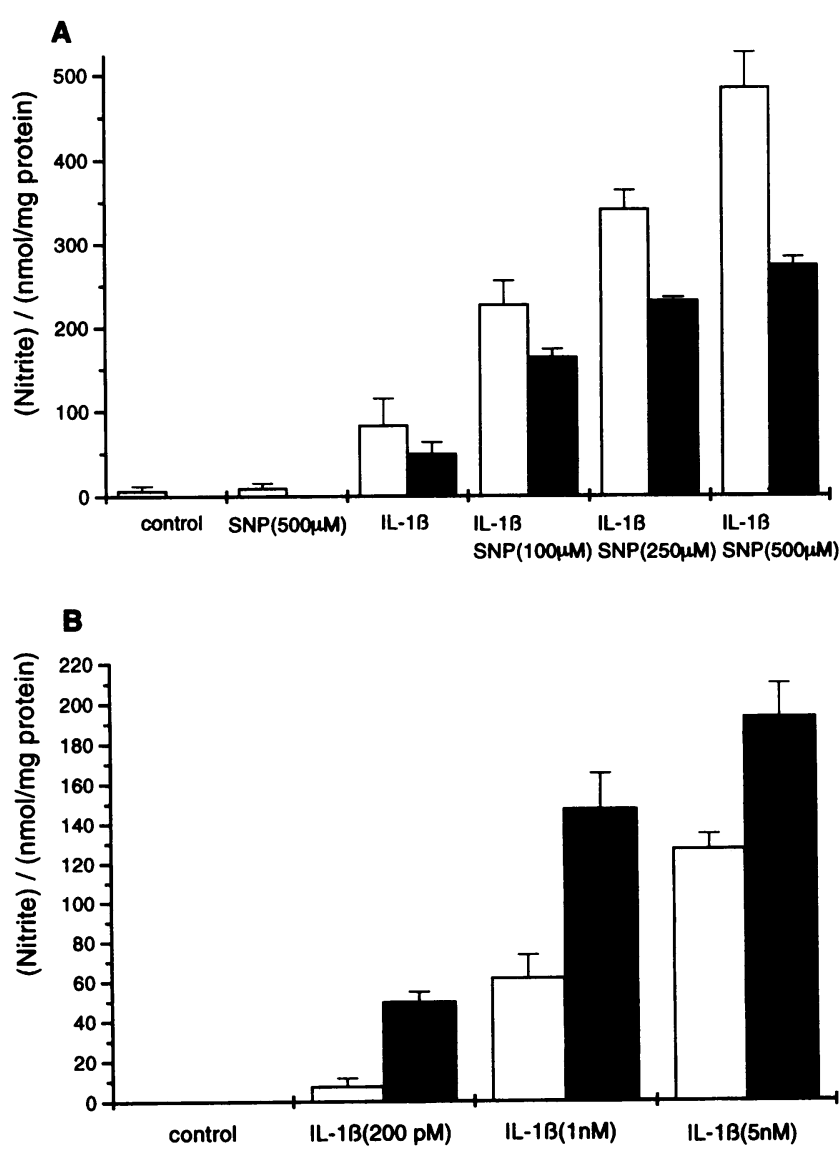

Figure 1. Nitric oxide amplifies IL-1 $\beta$-stimulated nitrite production in mesangial cells and vascular smooth muscle cells. $(A)$ Confluent mesangial cells (open bars) or rat aortic smooth muscle cells (hatched bars) were incubated for $16 \mathrm{~h}$ with vehicle (control), SNP ( $500 \mu \mathrm{M}), \mathrm{IL}-1 \beta$ $(2 \mathrm{nM})$, or combinations of IL-1 $\beta(2 \mathrm{nM})$ plus the indicated concentrations of SNP. $(B)$ Mesangial cells were incubated for $16 \mathrm{~h}$ with vehicle (control) or the indicated concentrations of IL-1 $\beta$ alone (open bars) or in combination with SNP $(250 \mu \mathrm{M})$. Thereafter, the cells were washed several times to remove all agents, and fresh medium with or without IL- $1 \beta$ but without SNP was added for a second incubation period of $6 \mathrm{~h}$. Nitrite production during this second incubation period was measured as a readout for NO synthase activity. Data are means \pm SD of four experiments.

Western blot analysis. Confluent mesangial cells were stimulated with or without agents for the indicated time periods. Cells were washed twice with PBS and harvested into $500 \mu \mathrm{l}$ lysis buffer $(50 \mathrm{mM}$ Tris/ $\mathrm{HCl}, \mathrm{pH}$ 7.6, $100 \mathrm{mM} \mathrm{NaCl}, 2 \mathrm{mM}$ EDTA, 2 mM EGTA, $1 \mathrm{mM}$ DTT, $1 \mathrm{mM}$ PMSF, $1 \%$ Triton X-100) and incubated for $30 \mathrm{~min}$ on ice. Thereafter the lysates were centrifuged for $15 \mathrm{~min}$ at $100,000 \mathrm{~g}$ at $4^{\circ} \mathrm{C}$. The supernatants were collected and the protein content was determined using the method of Bradford (22). $60 \mu \mathrm{g}$ of protein was then separated by SDS-PAGE ( $10 \%$ acrylamide gel), and, after blotting onto nitrocellulose (Schleicher \& Schuell, Richen, Switzerland), inducible NOS was immunodetected using a monoclonal antibody (Affiniti Research Products, Nottingham, U. K.) at a dilution of 1:500. Bands were detected by an alkaline phosphatase-conjugated second antibody (Sigma Chemical Co.).

\section{Results}

Fig. 1 A (open bars) shows that SNP, an NO-generating compound, was unable to induce NO synthase activity on its own. 


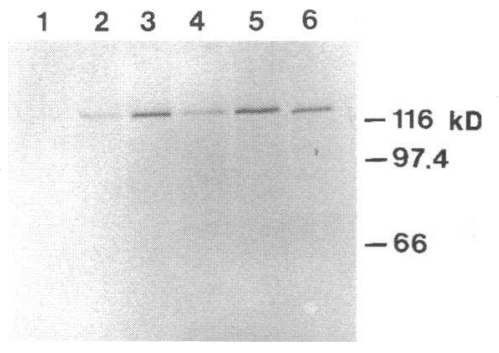

Figure 2. Nitric oxide amplifies IL- $1 \beta$-stimulated NO synthase protein expression in mesangial cells. Confluent cells were incubated with vehicle (lane 1$), \mathbb{L}-1 \beta$ ( 2 $\mathrm{nM}$, lane 2$), \mathrm{IL}-1 \beta$ plus SNP (500 $\mu \mathrm{M}$, lane 3$)$, IL- $1 \beta$ plus SNP $(250$ $\mu \mathrm{M}$, lane 4$), \mathrm{IL}-1 \beta$ plus SNAP ( $500 \mu \mathrm{M}$, lane 5 ), or IL-1 $\beta$ plus SNAP ( $250 \mu \mathrm{M}$, lane 6 ) for $20 \mathrm{~h}$. The cells were then lysed in ice-cold homogenization buffer followed by Western blot analysis with an antiserum specific for inducible NO synthase at a dilution of 1:500. Relative molecular mass markers are shown on the right. Bands were visualized with alkaline phosphatase.

In contrast, when SNP was added to cells together with IL-1 $\beta$, a cytokine known to induce NO synthase expression in mesangial cells (14-16), NO synthase activity and nitrite synthesis were markedly enhanced (Fig. $1 A$ ). Comparable data were obtained with SNAP, a second NO-generating compound that is structurally not related to SNP (data not shown). The amplifying effect of SNP is dependent on the concentration of IL$1 \beta$ used to trigger NO synthase expression and is most pronounced at submaximal concentrations of the cytokine (Fig. 1 $B$ ). The increased production of nitrite is paralleled by increased NO synthase protein (Fig. 2) and mRNA (Fig. 3) levels as determined by Western blot and Northern blot analyses, respectively. To obtain information on the time course of interaction between IL-1 $\beta$ and the NO donors, cells were incubated with IL- $\beta$ for $24 \mathrm{~h}$, and SNP was added for different periods during this stimulation. The data in Fig. 4 show that, for maximal potentiation of nitrite production, SNP must be present during the whole incubation period, suggesting that a sustained supply of NO is necessary for maximal augmentation of NO synthase expression.

We have shown recently that inducible NO synthase is expressed in mesangial cells in response to two principal classes of activating signals that interact in a synergistic fashion. These two groups of activators comprise inflammatory cytokines such as IL- $1 \beta$ and TNF- $\alpha$ and agents that elevate cellular levels of cAMP $(18,21,23)$. SNP only amplified the action of IL-1 $\beta$

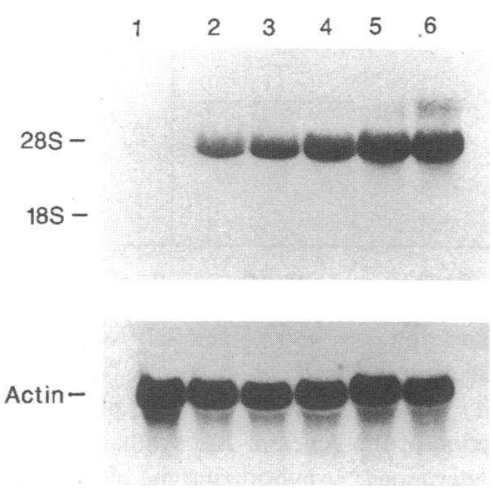

Figure 3. Nitric oxide amplifies interleukin IL$1 \beta$-stimulated NO synthase mRNA accumulation in mesangial cells. Confluent cells were incubated with SNP $(500$ $\mu \mathrm{M}$, lane 1$) ; \mathrm{IL}-1 \beta(2$ $\mathrm{nM}$, lane 2$)$, or IL-1 $\beta$ (2 nM) plus SNP $(1 \mu \mathrm{M}$ lane 3), $10 \mu \mathrm{M}$ (lane 4), $100 \mu \mathrm{M}$ (lane 5 ), or 500 $\mu \mathrm{M}$ (lane 6) for $20 \mathrm{~h}$. Total cellular RNA was successively hybridized

to ${ }^{32} \mathrm{P}$-labeled NO synthase and $\beta$-actin probes as described in Methods. The NO synthase mRNA was present as a single band of $\sim 4.5 \mathrm{~kb}$. In unstimulated cells there was no detectable NO synthase mRNA (18, 21).

\section{A}
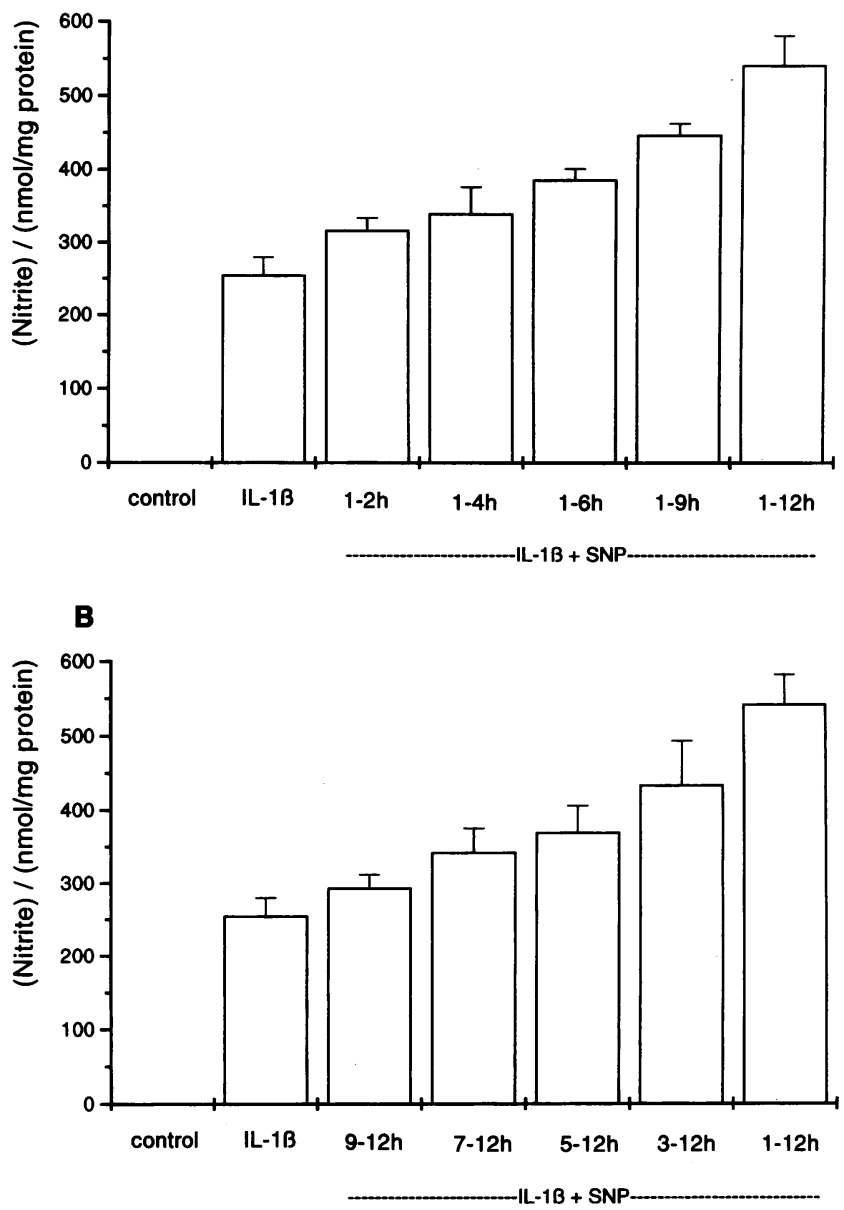

Figure 4. Critical time period for the interaction of IL-1 $\beta$ and SNP. Mesangial cells were incubated for $24 \mathrm{~h}$ with vehicle (control), IL-1 $\beta$ $(1 \mathrm{nM})$, or $\mathrm{IL}-1 \beta$ plus SNP $(250 \mu \mathrm{M})$. The indicated time periods refer to the presence of SNP in the stimulation medium (IL- $1 \beta$ was added at time 0 and was present throughout the 24-h incubation period). Thereafter, the medium was removed and used for nitrite determination. Results give the nitrite production during the last $12 \mathrm{~h}$ (in the absence of SNP) of the 24-h stimulation period and are expressed as means \pm SD of four experiments.

but not NO synthase induction triggered by cAMP (data not shown). To test the possibility that NO augmented cytokineinduced NO synthase expression by changing the level of cellular cGMP, we treated the cells with a membrane-permeable analogue, dibutyryl cGMP. Addition of dibutyryl cGMP did not induce NO synthase activity and did not alter IL- $1 \beta$-stimulated nitrite production (data not shown). Taken together, these findings suggest that amplification of NO synthase expression is an action of NO that is not mediated by cGMP and is selective for inflammatory cytokines like IL- $1 \beta$ and TNF- $\alpha$ (data not shown) without affecting cAMP induction of NO synthase.

To determine whether such a positive feedback loop triggered by NO is physiologically relevant, we used different compounds known to modulate NO formation in cytokine-stimulated mesangial cells. $\mathrm{IL}-1 \beta$ induction of NO synthase mRNA was substantially reduced by inclusion in the culture media of $N^{\mathrm{G}}$-monomethyl-L-arginine (L-NMMA), a guanidino-N-substituted $\mathrm{L}$-arginine analogue that acts as a competitive inhibitor 


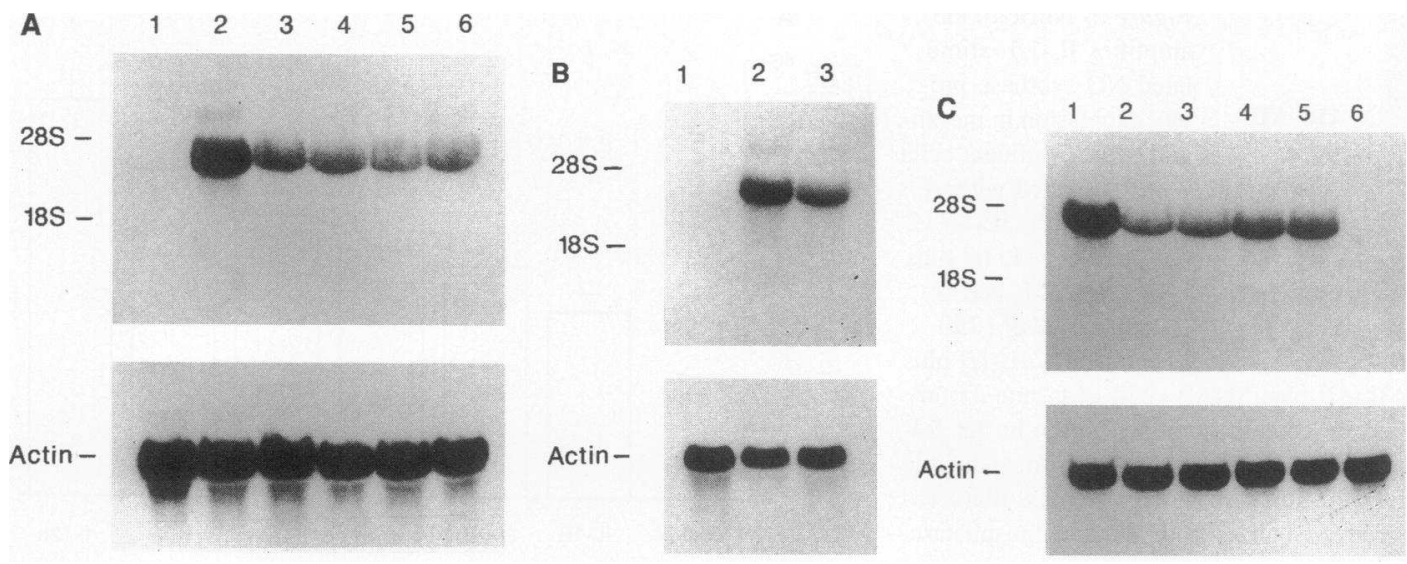

Figure 5. Effects of different agents on IL- $\beta$-stimulated NO synthase mRNA accumulation in mesangial cells. (A) L-NMMA inhibits IL-1 $\beta$ stimulated NO synthase mRNA levels. Confluent cells were incubated with vehicle (lane 1 ); IL-1 $\beta$ ( $2 \mathrm{nM}$, lane 2 ); or combinations of IL-1 $\beta$ ( 2 $\mathrm{nM}$ ) plus L-NMMA ( $100 \mu \mathrm{M}$, lane 3), $500 \mu \mathrm{M}$ (lane 4), $1 \mathrm{mM}$ (lane 5), or $5 \mathrm{mM}$ (lane 6 ) for $20 \mathrm{~h}$. (B) L-Arginine augments IL-1 $\beta$-stimulated NO synthase mRNA levels. Confluent cells were incubated with vehicle (lane 1$), \mathrm{IL}-1 \beta(2 \mathrm{nM})$ in medium containing $84 \mathrm{mg} / \mathrm{liter} \mathrm{L}$-arginine (lane 2 ), or IL-1 $\beta(2 \mathrm{nM}$ ) in medium free of L-arginine (lane 3 ) for $20 \mathrm{~h}$. (C) Inhibition of tetrahydrobiopterin synthesis inhibits IL-1 $\beta$-stimulated NO synthase mRNA levels. Confluent cells were incubated with vehicle (lane 6$)$; IL-1 $\beta$ ( $2 \mathrm{nM}$, lane 5); combinations of IL-1 $\beta$ ( $2 \mathrm{nM}$ ) plus DAHP $(0.5 \mathrm{mM}$, lane 4$), 1 \mathrm{mM}$ (lane 3 ), or $5 \mathrm{mM}$ (lane 2), or combinations of IL-1 $\beta$ (2 nM) plus DAHP (1 mM) plus sepiapterin (50 $\mu \mathrm{M}$, lane 1 ) for $20 \mathrm{~h}$. Total cellular RNA was successively hybridized to ${ }^{32} \mathrm{P}$-labeled NO synthase and $\beta$-actin probes as described in Methods.

of NO synthase, as shown in Fig. $5 \mathrm{~A}$. Conversely, changes of L-arginine concentration markedly modulate NO synthase mRNA levels, as shown in Fig. 5 B. In an alternative approach, we inhibited NO production by blocking the synthesis of tetrahydrobiopterin, an essential cofactor of NO synthase. Inhibition of the tetrahydrobiopterin synthetic enzyme GTP-cyclohydrolase I by 2,4-diamino-6-hydroxy-pyrimidine (DAHP) has been shown to prevent NO synthesis in fibroblasts (24), macrophages (25), vascular smooth muscle cells (26), and mesangial cells (27). As shown in Fig. $5 C$, DAHP markedly reduced IL$1 \beta$-stimulated NO synthase mRNA levels in a concentrationdependent manner. Addition of sepiapterin, which is intracellularly converted into tetrahydrobiopterin (24), completely reversed the inhibitory action of DAHP and even potentiated NO synthase mRNA levels (Fig. $5 C$ ). In this context it is worth noting that sepiapterin dose-dependently augments IL- $1 \beta$-stimulated NO synthesis, indicating that the availability of tetrahydrobiopterin limits the production of NO in stimulated mesangial cells (27).

To determine specifically the molecular mechanism by which NO amplifies NO synthase mRNA, we directly measured mRNA stability and transcriptional rate. The half-life of NO synthase mRNA was assessed by actinomycin D experiments. Mesangial cells were stimulated with IL-1 $\beta(1 \mathrm{nM})$ or a combination of IL-1 $\beta$ ( $1 \mathrm{nM})$ plus SNP $(500 \mu \mathrm{M})$ for $16 \mathrm{~h}$. Thereafter, actinomycin D ( $10 \mu \mathrm{g} / \mathrm{ml})$ was added to the cells to inhibit further transcription, and the NO synthase mRNA was measured at $1,2,4$, and $8 \mathrm{~h}$ as previously described (21). The half-life of NO synthase message stimulated by IL- $1 \beta$ alone was $1.2 \pm 0.2$ $\mathrm{h}($ mean $\pm \mathrm{SD}, n=4)$. SNP did not significantly alter NO synthase mRNA stability, and a half-life of $1.6 \pm 0.3 \mathrm{~h}$ (mean $\pm S D$, $n=2$ ) was calculated ( $P>0.05$, by Student's $t$ test). Nuclear run-on experiments were performed to determine the transcriptional rate of the NO synthase gene. IL- $1 \beta$ markedly increased NO synthase gene transcription in mesangial cells, as described previously (21). Addition of SNP alone has no effect on NO synthase gene transcription, but it potently augmented IL- $1 \beta-$ induced transcriptional rate by $\sim 130 \%$ (Fig. 6). In summary, these results suggest that $\mathrm{NO}$ acts as an autocrine mediator that upregulates IL- $1 \beta$-induced NO synthase gene expression in mesangial cells and thus leads to an optimal generation of NO by the cells. This positive feedback mechanism of NO serving to maximally amplify its own production is not restricted to renal mesangial cells, but it is also observed in vascular smooth muscle cells derived from rat aorta, as shown in Fig. $1 \mathrm{~A}$ (hatched bars), and thus may be a general mechanism operative

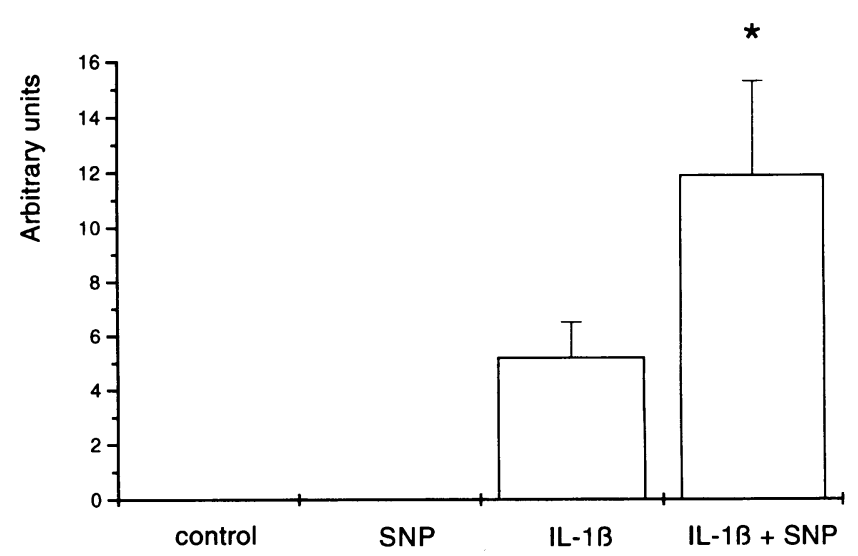

Figure 6. NO synthase gene transcription in IL- $\beta$ - and SNP-stimulated mesangial cells. Mesangial cells were incubated with vehicle (control), SNP $(500 \mu \mathrm{M}), \operatorname{IL}-1 \beta(1 \mathrm{nM})$, or a combination of IL- $1 \beta$ plus SNP for $16 \mathrm{~h}$. The rate of transcription of the genes of NO synthase or $\beta$ actin by isolated nuclei was determined by hybridizing the elongated, labeled RNA transcripts to NO synthase cDNA or a $\beta$-actin probe immobilized onto GeneScreen membranes and evaluation by PhosphorImaging. Results are means \pm SD of three independent experiments. Significant difference from stimulation with IL- $1 \beta$ alone. ${ }^{*} P<0.05$; Student's $t$ test. 
in cells and tissues that are able to express the inducible form of NO synthase.

\section{Discussion}

These results raise several questions as to the mechanism of NO-induced NO synthase expression, the physiological role of this positive feedback loop, and the possible termination of this positively regulated process. The precise mechanism by which NO amplifies NO synthase expression remains to be clarified but may be related to the ability of NO to activate the transcription factor $\mathrm{NF} \kappa \mathrm{B}$. Lander et al. (28) found that NO-generating compounds such as SNP and SNAP induce NF $\kappa$ B binding activity in peripheral blood mononuclear cells, an effect that is not mimicked by a cell-permeable cGMP analogue. In this context it is important to note that activation of $N F \kappa B$ is critical in the induction of NO synthase in macrophages (29-31) and mesangial cells (23). Furthermore, we have reported recently that pyrrolidine dithiocarbamate, a potent inhibitor of $N F \kappa B$, completely inhibits NO synthase induction in response to IL$1 \beta$ without affecting cAMP-induced NO synthase expression (23). These observations are compatible with the data reported in the present paper showing that NO amplifies IL- $\beta$-induced, but not cAMP-stimulated, NO synthase activity. The physiological role of the described potent amplification mechanism of NO generation may be to rapidly provide injured cells with a powerful host defense mechanism that also may form the basis for the dramatic production of NO in acute and chronic inflammatory diseases. Evidence for the presence of the L-arginine NO pathway in the renal glomerulus in vivo and its relevance for several types of experimental glomerulonephritis has been provided by the work of Cattell and Cook (9) and Jansen et al. (32). Moreover, Weinberg et al. (33) reported that oral administration of L-NMMA prevents the development of glomerulonephritis and reduces the intensity of inflammatory arthritis in MRL-lpr/lpr mice that develop a spontaneous autoimmune disease. It is tempting to suggest that the regional or systemic use of compounds that block the positive amplification cycle of NO production may be of value in therapy to autoimmune diseases. The careful control of this extremely reactive molecule is essential for the prevention of deleterious inflammatory reactions. Powerful negatively acting regulatory pathways are required to terminate amplification loops such as the one described in this paper. Recently, Moncada and co-workers (34) reported that NO generators markedly inhibit macrophage NO synthase activity in vitro in an irreversible fashion. However, a high concentration of NO donors was required to get significant inhibition of the enzyme. Incubation of cytosolic fraction of IL- $\beta$-stimulated mesangial cells with SNAP gave a dose-dependent inhibition of NO synthase activity as measured by the citrulline assay (Fig. 7). Significant reduction of NO synthase activity required concentrations of SNAP as high as $500 \mu \mathrm{M}$ (Fig. 7). These data show that NO donors not only potentiate the effects of IL- $1 \beta$ on the expression of NO synthase mRNA (Fig. 2), synthesis of NO synthase (Fig. 3), and production of NO (Fig. 1), but they also inhibit IL- $\beta$-induced activity of the enzyme (Fig. 7). Therefore, NO may provide an additional level of modulation with an effect on the amount of the enzyme combined with the opposite effect on its activity. Can these seemingly disparate results be reconciled? We suggest that NO acts as positive feedback regulator to rapidly amplify its own synthesis, but as soon as a critical threshold of

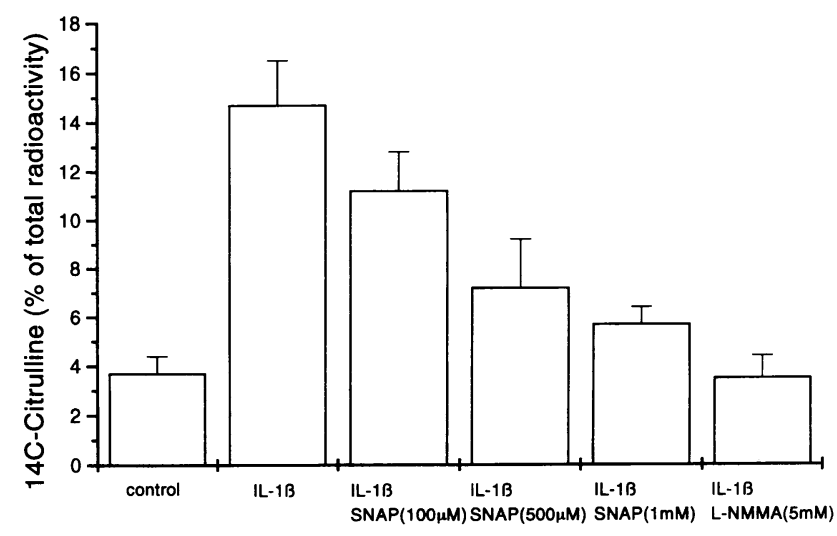

Figure 7. Inhibition of IL-1 $\beta$-stimulated NO synthase activity extracted from mesangial cells by SNAP. Cells were incubated with IL-1 $\beta$ (2 $\mathrm{nM}$ ) for $20 \mathrm{~h}$ and thereafter washed and lysed. Cell cytosols were prepared from lysates and incubated in the presence and absence of $\mathrm{L}$ NMMA $(5 \mathrm{mM})$ for $30 \mathrm{~min}$ at $37^{\circ} \mathrm{C}$ with $5 \mathrm{nCi} \mathrm{L-}\left[{ }^{14} \mathrm{C}\right]$ arginine. The incubations were terminated and the formation of $\mathrm{L}-\left[{ }^{14} \mathrm{C}\right]$ citrulline was quantified as described in Methods. The specific nitric oxide synthase activity was calculated as the L-NMMA-sensitive formation of $\mathrm{L}-\left[{ }^{14} \mathrm{C}\right]$ citrulline per minute per milligram of protein. Data are means $\pm S D$ of three experiments.

NO production is reached NO now functions as a negative feedback modulator, to terminate its production finally in an irreversible manner. In an alternative scenario, NO-triggered amplification of NO synthase expression is suppressed simply because of substrate depletion. The remarkably high turnover of L-arginine may reduce extracellular L-arginine concentration to an extent that it becomes rate limiting for NO synthase activity and thus provides a stop signal for further NO synthase expression. The phenomenon of NO-modulated NO synthase expression and activity may have broad implications for understanding the regulation of NO synthase activity and may help to develop new pharmacological approaches applicable to conditions of pathological NO overproduction.

\section{Acknowledgments}

We thank Dr. Klaus Vosbeck and Dr. H. Müller (Ciba-Geigy Ltd., Basel, Switzerland) for kindly providing recombinant human IL- $1 \beta$ and assistance with the nuclear run-on assays, respectively. We gratefully acknowledge Dr. J. Cunningham for providing the pMAc-NOS cDNA clone.

This work was supported by grants from the Swiss National Science Foundation (31-33653.92) and from the Commission of the European Union (Biomed I, BMH1-CT92-1893).

\section{References}

1. Moncada, S., R. M. J. Palmer, and E. A. Higgs. 1991. Nitric oxide: physiology, pathophysiology and pharmacology. Pharmacol. Rev. 43:109-142.

2. Snyder, S. 1992. Nitric oxide and neurons. Curr. Opin. Neurobiol. 2:323327.

3. Nathan, C. 1992. Nitric oxide as a secretory product of mammalian cells. FASEB (Fed. Am. Soc. Exp. Biol.) J. 6:3051-3064.

4. Kolb, H., and V. Kolb-Bachofen. 1992. Nitric oxide: a pathogenetic factor in autoimmunity. Immunol. Today. 13:157-160.

5. Moncada, S., and A. Higgs. 1993. The L-arginine-nitric oxide pathway. $N$. Engl. J. Med. 329:2002-2012.

6. Änggard, E. 1994. Nitric oxide: mediator, murderer, and medicine. Lancet. 343:1199-1206. 
7. Ialenti, A., S. Moncada, and M. Di Rosa. 1993. Modulation of adjuvant arthritis by endogenous nitric oxide. Br. J. Pharmacol. 110:701-706.

8. Pfeilschifter, J., D. Kunz, and H. Mühl. 1993. Nitric oxide: an inflammatory mediator of glomerular mesangial cells. Nephron. 64:518-525.

9. Cattell, V., and H. T. Cook. 1993. Nitric oxide: role in the physiology and pathology of the glomerulus. Exp. Nephrol. 1:265-280.

10. Lipton, S. A., Y.-B. Chol, Z.-H. Pan, S. Z. Lei, H.-S. V. Chen, N. J. Sucher, J. Loscalzo, D. J. Singel, and J. S. Stamler. 1993. A redox-based mechanism for the neuroprotective and neurodestructive effects of nitric oxide and related nitrosocompounds. Nature (Lond.). 364:626-632.

11. Pfeilschifter, J. 1989. Cross-talk between transmembrane signalling systems: a prerequisite for the delicate regulation of glomerular haemodynamics by mesangial cells. Eur. J. Clin. Invest. 19:347-361.

12. Schultz, P. J., A. E. Schorer, and L. Raij. 1990. Effects of endotheliumderived relaxing factor and nitric oxide on rat mesangial cells. Am. J. Physiol. 258:F162-F167.

13. Marsden, P. A., T. A. Brock, and B. J. Ballermann. 1990. Glomerular endothelial cells respond to calcium-mobilizing agonists with release of EDRF. Am. J. Physiol. 258:F1295-F1303.

14. Pfeilschifter, J., and H. Schwarzenbach. 1990. Interleukin 1 and tumor necrosis factor stimulate cGMP in rat renal mesangial cells. FEBS (Fed. Eur. Biochem. Soc.) Lett. 273:185-187.

15. Pfeilschifter, J., P. Rob, A. Mülsch, J. Fandrey, K. Vosbeck, and R. Busse 1992. Interleukin $1 \beta$ and tumour necrosis factor $\alpha$ induce a macrophage-type of nitric oxide synthase in rat renal mesangial cells. Eur. J. Biochem. 203:251-255.

16. Mühl, H., D. Kunz, P. Rob, and J. Pfeilschifter. 1993. Cyclosporin derivatives inhibit interleukin $1 \beta$ induction of nitric oxide synthase in renal mesangial cells. Eur. J. Pharmacol. 249:95-100.

17. Pfeilschifter, J., and K. Vosbeck. 1991. Transforming growth factor $\beta 2$ inhibits interleukin $1 \beta$ - and tumour necrosis factor $\alpha$-induction of nitric oxide synthase in rat renal mesangial cells. Biochem. Biophys. Res. Commun. 175:372379.

18. H. Mühl, D. Kunz, and J. Pfeilschifter. 1994. Expression of nitric oxide synthase in rat glomerular mesangial cells mediated by cyclic AMP. Br. J. Phar macol. 112:1-8.

19. Sambrook, J., E. F. Fritsch, and T. Maniatis. 1989. Molecular Cloning: A Laboratory Manual. Cold Spring Harbor Laboratory, Cold Spring Harbor, NY. pp. 7.19-7.22

20. Lyons, C. R., G. J. Orloff, and J. M. Cunnigham. 1992. Molecular cloning and functional expression of an inducible nitric oxide synthase from a murine macrophage cell line. J. Biol. Chem. 267:6370-6374.

21. Kunz, D., H. Mühl, G. Walker, and J. Pfeilschifter. 1994. Two distinct signaling pathways trigger the expression of nitric oxide synthase in rat renal mesangial cells. Proc. Natl. Acad. Sci. USA. 91:5387-5391.

22. Bradford, M. M. 1976. A rapid and sensitive method for the quantitation of microgram quantities of protein utilizing the principle of protein-dye binding. Anal. Biochem. 72:248-254.

23. Eberhardt, W., D. Kunz, and J. Pfeilschifter. 1994. Pyrrolidine dithiocarbamate differentially affects interleukin $1 \beta$-and cAMP-induced nitric oxide synthase expression in rat renal mesangial cells. Biochem. Biophys. Res. Commun. 200:162-170.

24. Werner-Felmayer, G., E. R. Werner, D. Fuchs, A. Hausen, G. Reibnegger, and $\mathrm{H}$. Wachter. 1990. Tetrahydrobiopterin-dependent formation of nitrite and nitrate in murine fibroblasts. J. Exp. Med. 172:1599-1607.

25. Schoedon, G., M. Schneemann, S. Hofer, L. Guerrero, N. Blau, and A. Schaffner. 1993. Regulation of the L-arginine-dependent and tetrahydrobiopterindependent biosynthesis of nitric oxide in murine macrophages. Eur. J. Biochem. 213:833-839.

26. Gross, S. S., and R. Levi. 1992. Tetrahydrobiopterin synthesis. J. Biol. Chem. 267:25722-25729.

27. Mühl, H., and J. Pfeilschifter. 1994. Tetrahydrobiopterin limits nitric oxide generation in interleukin $1 \beta$-stimulated rat glomerular mesangial cells. Kidney Int. 46:1302-1306.

28. Lander, H. M., P. Sehajpal, D. M. Levine, and A. Novogrodsky. 1993. Activation of human peripheral blood mononuclear cells by nitric oxide-generating compounds. $J$. Immunol. 105:1509-1516.

29. Sherman, M. P., E. E. Aeberhard, V. Z. Wong, J. M. Griscavage, and L. J. Ignarro. 1993. Biochem. Biophys. Res. Commun. 191:1301-1308.

30. Mülsch, A., B. Schray-Utz, P. I. Mordvintcev, S. Hauschildt, and R. Busse. 1993. Diethyldithiocarbamate inhibits induction of macrophage NO synthase. FEBS (Fed. Eur. Biochem. Soc.) Lett. 321:215-218.

31. Xie, Q., Y. Kashiwabara, and C. Nathan. 1994. Role of transcription factor NF- $\kappa$ B/Rel in induction of nitric oxide synthase. J. Biol. Chem. 269:4705-4708.

32. Jansen, A., T. Cook, G. M. Taylor, P. Largen, V. Riveros-Moreno, S. Moncada, and V. Cattell. 1994. Induction of nitric oxide synthase in rat immune complex glomerulonephritis. Kidney Int. 45:1215-1219.

33. Weinberg, J. B., D. L. Granger, D. S. Pisetsky, M. F. Seldin, M. A. Misukonis, S. N. Mason, A. M. Pippen, P. Ruiz, E. R. Wood, and G. S. Gilkeson. 1994. The role of nitric oxide in the pathogenesis of spontaneous murine autoimmune disease: increased nitric oxide production and nitric oxide synthase expression in MRL-lpr/lpr mice, and reduction of spontaneous glomerulonephritis and arthritis by orally administered $N^{\mathrm{G}}$-monomethyl-L-arginine. J. Exp. Med. 179:651-660.

34. Assreny, J., F. Q. Cunha, F. Y. Liew, and S. Moncada. 1993. Feedback inhibition of nitric oxide synthase activity by nitric oxide. $\mathrm{Br}$. J. Pharmacol. 108:833-837. 